\title{
PENINGKATAN PENGETAHUAN DAN KEMAMPUAN KADER POSYANDU DALAM STIMULASI I NTERVENSI DAN DETEKSI DINI TUMBUH KEMBANG ANAK DI KELURAHAN HADIMULYO BARAT KOTA METRO
}

\author{
Riyanto*, Herlina, Islamiyati \\ Prodi Kebidanan Metro, Poltekkes Tanjungkarang, Indonesia \\ Coresponding Author: riyanto@poltekkes-tjk.ac.id
}

\begin{abstract}
The golden period of growth and development of children occurs from the beginning of pregnancy until birth and children are 2 years or 1000 days. The impact of children not being stimulated can be growth disorders and delays. The problem of delays or deviations in child development is still a problem for children in Indonesia. The role of cadres needs to be increased to stimulate early detection and early intervention of developmental deviations. This activity aims to improve the knowledge and skills of cadres in early stimulation and intervention for growth and development, so as to be able to find early developmental deviations in toddlers. This activity uses a training method with education using modules and simulations using a developmental pre-screening questionnaire. The participants of the activity were the Melati Cadre and Kenanga Cadre totaling 14 people and 19 infants under five in the West Hadimulyo sub-district, Metro Central district, Metro city. Evaluation of activities was carried out by pre-test and post-test and assessment of the skills of cadres to stimulate development using developmental pre-screening questionnaires. The results of the activity obtained increased knowledge and skills of Integrated Service Post cadres to stimulate development with a developmental pre-screening questionnaire. The enthusiasm of the cadres in this activity and the support of partners, so that the activity can be smooth and successful. It is necessary to follow up the implementation of cadre skills directly during early stimulation activities and interventions for the growth and development of children of various ages.
\end{abstract}

Keywords: Stimulation of child development; cadre training; cadre skills.

\begin{abstract}
Abstraks
Masa emas pertumbuhan dan perkembangan anak terjadi sejak awal kehamilan sampai kelahiran dan anak berumur 2 tahun atau 1000 hari. Dampak anak tidak dilakukan stimulasi dapat gangguan pertumbuhan dan keterlambatan. Masalah keterlambatan atau penyimpangan perkembangan anak masih menjadi masalah bagi anak di Indonesia. Peran kader perlu ditingkatkan untuk stimulasi deteksi dini dan intervensi penyimpangan perkembangan secara dini. Kegiatan ini bertujuan untuk meningkatkan pengetahuan dan ketrampilan kader dalam stimulasi dini dan intervensi tumbuh kembang, sehingga mampu menemukan penyimpangan dini tumbuh kembang pada balita. Kegiatan ini menggunakan metode pelatihan dengan edukasi menggunakan modul dan simulasi menggunakan alat kuesioner pra skrining perkembangan. Peserta kegiatan adalah Kader Melati dan Kader Kenanga berjumlah 14 orang dan bayi balita berjumlah 19 orang di kelurahan Hadimulyo Barat kecamatan Metro Pusat kota Metro. Evaluasi kegiatan dilakukan dengan pre test dan post test serta penilaian ketrampilan kader melakukan stimulasi perkembangan menggunakan alat alat kuesioner pra skrining perkembangan. Hasil kegiatan diperoleh peningkatan pengetahuan dan ketrampilan kader Pos Pelayanan Terpadu untuk melakukan stimulasi perkembangan dengan kuesioner pra skrining perkembangan. Antusias kader dalam kegiatan ini dan dukungan mitra, sehingga kegiatan dapat lancar dan sukses. Perlu tindak lanjut implementasi ketrampilan kader langsung pada saat kegiatan stimulasi dini dan intervensi tumbuh kembang anak dengan berbagai umur.
\end{abstract}

Kata kunci: Stimulasi perkembangan anak; pelatihan kader; ketrampilan kader.

@2021 Penerbit PS2PM FISIPKUM UNSERA Segala bentuk plagiarisme dan penyalahgunaan hak kekayaan intelektual akibat diterbitkannya artikel pengabdian masyarakat ini sepenuhnya menjadi tanggung jawab penulis

Riyanto, Herlina, Islamiyati, Peningkatan Pengetahuan dan Kemampuan Kader Posyandu dalam Stimulasi I Ntervensi dan Deteksi Dini Tumbuh Kembang Anak di Kelurahan Hadimulyo Barat Kota Metro 


\section{PENDAHULUAN}

Asuhan pertumbuhan dan perkembangann anak 0-5 tahun penting dilakukan secara menyeluruh dan bermutu, terkoordinasi dengan mengikutkan peran serta keluarga, komunitas, organisasi profesi, lembaga sosial kemasyarakatan, pemerintah, termasuk non pemerintah dengan penyelenggaraan kegiatan SDIDTK atau Stimulasi, Deteksi dan Intervensi Dini Tumbuh Kembang. Agar anak pada masa bayi dan balita sebagai usia dini dapat mengalami pertumbuhan dan perkembangan secara optimal pada periode emas (golden period) (Kemenkes RI, 2020).

Masa emas terjadi sejak awal kehamilan sampai kelahiran dan anak berumur 2 tahun atau 1000 hari. Periode yang kritis pada anak, bila tidak dilakukan stimulasi dapat berdampak gangguan pertumbuhan dan keterlambatan (Soetjinngsih \& Ranuh, 2017) dan anak tidak tumbuh dan berkembang secara optimal, baik perkembangan fungsi organ fisik, psikologis, kecerdasan emosional dan kecerdasan sosial serta kecerdasan majemuk berdasarkan potensi bawaan atau genetik (Kemenkes RI., 2016).

Angka keterlambatan tumbuh kembang anak masih relatif tinggi, secara umum terdapat keterlambatan perkembangan antara 5-10\%. Anak yang mengalami keterlambatan perkembangan motorik terjadi 2 dari 1000 bayi dan anak terjadi terjadi perkembangan yang lambat, terjadi masalah pendengaran sebanyak tiga sampai enam dari 1000 bayi dan masalah kurangnya kecerdasan dan lambat bicara terdapat 1 dari seratus anak (Kadi, Garna, \& Fadlyana, 2016).

Permasalahan anak dalam pertumbuhan dan perkembangannya berdasarkan hasil Riset Kesehatan Dasar di kota Metro dan provinsi Lampung menunjukkan bahwa terdapat anak usia 0-59 tahun tidak dipantau pertumbuhannya $(11,39 \%)$, tidak diukur Tinggi Badan atau Berat 
Badan (33,3\%). Sedangkan, untuk provinsi Lampung indeks perkembangan anak usia dini umur 36-59 bulan diperkotaan mencapai 91,94\% dan dipedesaan lebih rendah $(85,47 \%)$, kemampuan aspek sosial emosional baru mencapai 78,02\% dan aspek kemampuan belajar mencapai 93,27. Artinya belum tercapai $100 \%$ dan berpotensi mengalami masalah pertumbuhan dan penyimpangan perkembangan yang tidak terdeteksi secara dini (Badan Litbang Kemenkes RI, 2019).

Analisis situasi hasil survei di Posyandu Melati kelurahan Hadimulyo Barat kecamatan Metro Pusat terdapat 7 kader, belum ada yang mendapatkan pelatihan stimulasi dan deteksi dini penyimpangan tumbuh kembang. Namun, semua kader sudah mendapatkan pelatihan penggunaan dan pengisian buku KIA serta terdapat satu kader yang pernah mendapatkan penyuluhan tentang tumbuh kembang anak.
Salah satu upaya menyelesaikan masalah di atas, melalui upaya meningkatkan derajat kesehatan anak adalah dengan melakukan pembinaan tumbuh kembang anak secara komprehensif dan berkualitas adalah diselenggarakannya kegiatan stimulasi, deteksi, dan intervensi dini tumbuh kembang (SDIDTK) anak. Kegiatan SDIDTK ini dilakukan menyeluruh dan terkoordinasi serta diselenggarakan dalam bentuk kemitraan antara keluarga, masyarakat (kader kesehatan, kader Pos PAUD, organisasi profesi, LSM) dan tenaga profesional serta kebijakan yang berpihak pada pelaksanaan program SDIDTK. Kegiatan deteksi dini tumbuh kembang balita dan anak prasekolah merupakan serangkaian kegiatan yang terintegrasi dengan PAUD/TK dan kegiatan Posyandu (Kemenkes RI, 2016).

Kader Posyandu penting diberdayakan dengan tujuan meningkatkan pengetahuan dan ketrampilan kader dalam SDIDTK, 
sehingga mampu menemukan penyimpangan dini tumbuh kembang pada balita dan lebih mudah diberikan intervensi dan anak perkembangan emas anak dapat sehat serta optimal.

\section{METODE PELAKSANAAN}

Kegiatan pengabdian kepada masyarakat (PKM) dilaksanakan di Posyandu Kenanga keluarahan Hadimulyo Barat kecamatan Metro Pusat kota Metro merupakan daerah kelurahan Pembinaan Politeknik Kesehatan Tanjung Karang Program Studi Kebidanan Metro. Sasaran kegiatan ini adalah dua Posyandu, yaitu Posyandu Kenanga terdiri atas jumlah kader 7 orang dan bayi balita berjumlah 12 orang. Sedangkan, Posyandu Melati terdapat 7 kader dan 7 bayi balita. Pelaksana Tim kegiatan ini terdiri atas 4 orang Dosen dan 4 Mahasiswa Prodi Kebidanan Metro yang telah mendapatkan kompetensi stimulasi, intervensi dan deteksi dini penyimpangan tumbuh kembang
(SDIDTK) yang dilaksanakan pada bulan Oktober - Desember 2017.

Kegiatan PKM ini dilaksanakan menggunakan metode:

1. Edukasi tentang SDIDTK yang dilaksanakan dengan metode:

a. Pre test terdiri atas 10 item pertanyaan dalam bentuk pilihan ganda;

b. Ceramah dan Diskusi;

2. Pelatihan tentang SDIDTK dilaksanakan dengan metode:

a. Studi kasus;

b. Simulasi untuk praktik SDIDTK oleh Tim menggunakan instrumen Kuesioner Pra Skrining Perkembangan (KPSP); c. Kader Posyandu mengulangi Simulasi praktik SDIDTK oleh Tim menggunakan instrumen Kuesioner Pra Skrining Perkembangan (KPSP) dan didampingi sekaligus disupervisi oleh Tim;

3. Evaluasi dilakukan pada akhir kegiatan dengan metode: 
a. Observasi ketrampilan Kader Posyandu melakukan SDIDTK disupervisi oleh Tim;

b. Post test dengan soal yang sama untuk pre test.

Persiapan kegiatan PKM dilakukan dimulai dengan koordinasi Tim dengan Mitra Puskesmas Yosodadi kecamatan Metro Pusat, Pos Kesehatan Kelurahan dan Kader Posandu Kenanga Hadimulyo Timur. Persiapan materi dalam bentuk modul SDIDTK dan mencetaknya, serta Kit SDIDTK. Selain itu, memperbanyak instrumen KPSP.

Kegiatan PKM dilanjutkan dengan Simulasi dengan praktik stimulasi, intervensi dan deteksi dini penyimpangan tumbuh kembang (SDIDTK). Simulasi praktik SDIDTK meliputi pengukuran pertumbuhan. Selain itu, praktik stimulasi perkembangan anak sesuai umur menggunakan KPSP dilakukan oleh Tim, dibantu oleh Mahasiswa. Kader Posyandu diberikan simulasi praktik melakukan SDIDTK menggunakan alat KPSP pada bayi dan balita yang hadir. Instrumen KPSP untuk mengukur perkembangan anak terdiri atas 22 digunakan sesuai umur anak untuk SDIDTK dimulai bayi umur 3 bulan, selanjutnya $6,9,12,15,18,21,24,30,36$, $42,48,54,60,66,72$ bulan.

Instrumen KPSP umur anak 12 bulan dapat dilihat pada tabel 1 . Prosedur penggunaan KPSP meluputi: (1) Tanyakan tanggal lahir bayi untuk menghitung umur bayi/ anak, link (cari) KPSP sesuai umur dalam bulan; (2) Isilah KPSP sesuai pertanyaan. Ada kuesioner yang cukup dijawab oleh Ibu dan ada kuesioner dalam bentuk perintah kepada Ibu/ Pengasuh anak untuk melaksanakan tugas yang tertulis pada KPSP. Pertanyaan dijawab berurutan satu persatu. Setiap pertanyaan hanya mempunyai satu jawaban Ya atau Tidak; (3) Teliti kembali semua pertanyaan dan jawaban; (4) Hitunglah jawaban Ya, bila dijawab bisa atau sering atau kadangkadang dan Jawaban Tidak, bila 
jawaban belum pernah atau tidak pernah. Kesimpulan SDIDTK: (1) bila jawaban Ya = 9-10, perkembangan anak sesuai umur dengan tahapan perkembangan (S); (2) bila jawaban Ya $=7$ atau 8 , perkembangan anak meragukan (M); (3) bila jawaban Ya $=6$ atau kurang, kemungkinan ada penyimpangan (P). Terakhir rincilah jawaban Tidak pada nomor berapa menurut tingkat keterlambatan (motorik kasar, motorik halus, bicara dan bahasa serta sosialisasi dan kemandirian (Kemenkes RI., 2016). Contoh KPSP umur 12 bulan dapat dilihat pada Tabel 1.

Kader sangat antusias mengikuti kegiatan pelatihan. Kader diberikan kesempatan untuk mengulangi Simulasi pada bayi dan balita yang lain dengan didampingi oleh Tim, sekaligus disupervisi. Supervisi dilakukan untuk menilai, memberikan perbaikan selama melakukan praktek SDIDTK dan memberikan pujian pada Kader. Pada akhir kegiatan Kader Posyandi diukur kembali (post test) tingkat pengetahuan SDIDTK.

\section{HASIL DAN PEMBAHASAN}

Kegiatan PKM ini bertajuk: “Stimulasi Intervensi dan Deteksi Dini Tumbuh Kembang Anak Kita Tingkatkan Generasi Sehat yang Berkualitas". Bertujuan untuk meningkatkan pengetahuan dan kemampuan Kader Posyandu dan Ibu bayi balita tentang SDIDTK pada bayi balita dengan peserta 7 kader Posyandu Kenanga Hadimulyo Barat dan 12 ibu yang mempunyai bayi balita dan 7 kader Melati dengan 7 ibu yang membawa bayi balitanya.

PKM ini diawali dengan survei untuk pengkajian permasalahan khususnya kesehatan ibu dan anak, sehingga ditemukan berbagai masalah maupun risiko atau potensi masalah. Permasalahan yang ditemukan adalah potensi anak mengalami keterlambatan perkembangan dan gangguan pertumbuhan. Solusi yang disepakati 
dengan mitra adalah melakukan kerjasama untuk meningkatkan pengetahuan dan ketrampilan kader Posandu dan ibu balita dalam

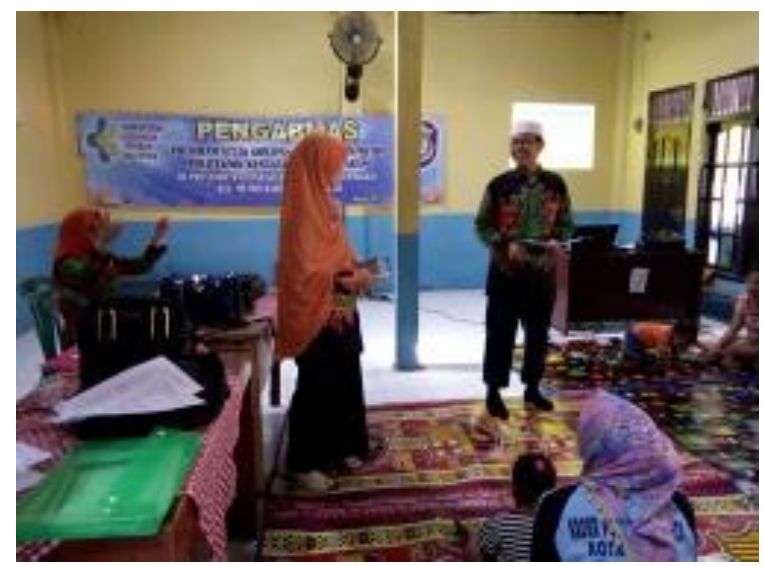

Gambar 1. Tim Memberikan Edukasi SDIDTK

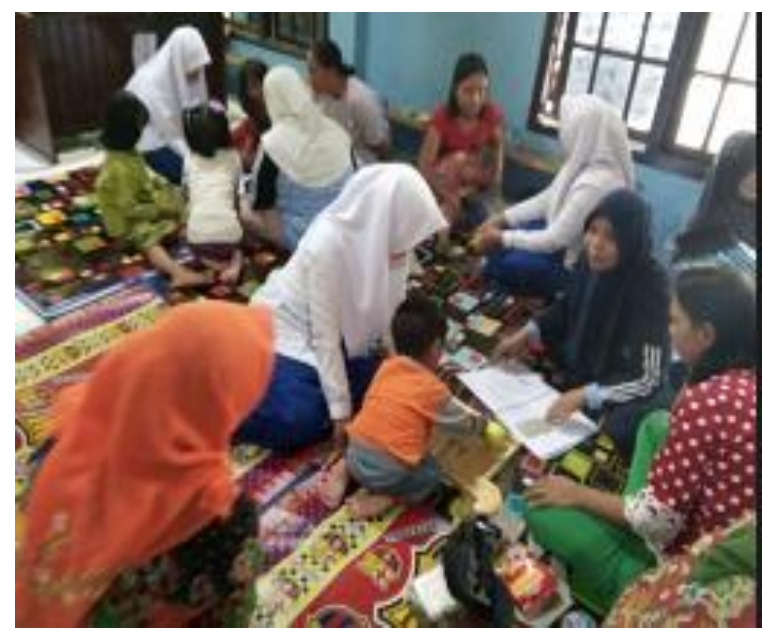

Gambar 3. Kader Latihan Mengisi KPSP

\section{Peningkatan Pengetahuan Kader} posyandu stimulasi intervensi dan deteksi dini tumbuh kembang anak dengan edukasi dan pelatihan. Kegitan ini sudah berjalan untuk tahun ketiga.

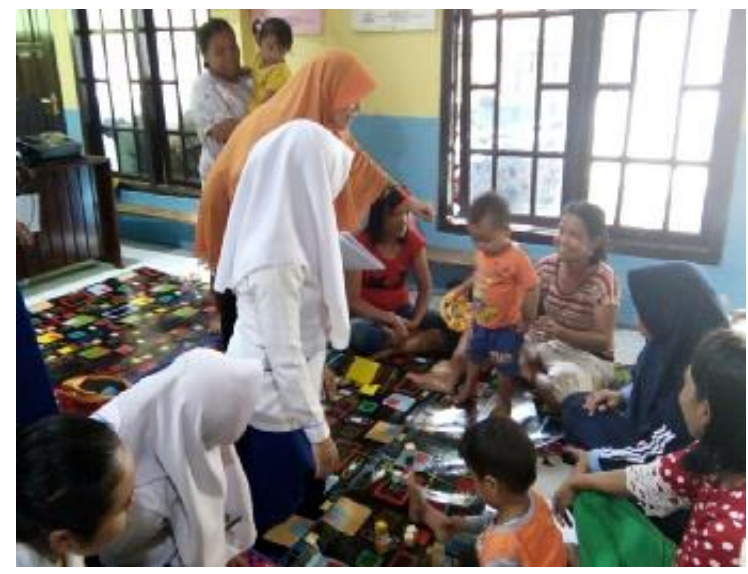

Gambar 2. Tim Memberikan Pelatihan SDIDTK

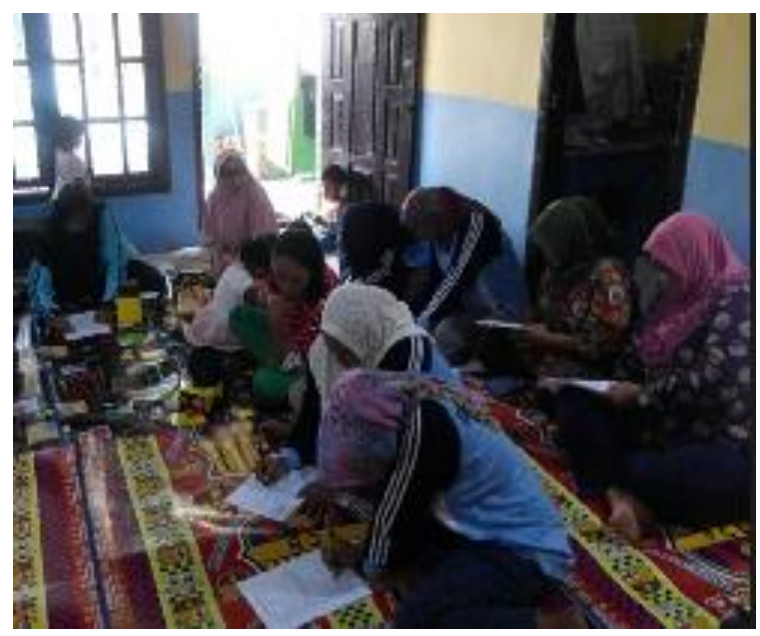

Gambar 4. Post Test Akhir Kegiatan

Edukasi sangat diperlukan dilakukan kepada kader Posyandu sebagai peningkatan pemberdayaan

Riyanto, Herlina, Islamiyati, Peningkatan Pengetahuan dan Kemampuan Kader Posyandu dalam Stimulasi I Ntervensi dan Deteksi Dini Tumbuh Kembang Anak di Kelurahan Hadimulyo Barat Kota Metro 
dengan peningkatan pengetahuan. Kegiatan PKM pertama adalah edukasi SDIDTK dengan sub-sub materi: (1) Pentingnya tumbuh kembang dan batasan pertumbuhan serta perkembangan; (2) Faktorfaktor yang mempengaruhi tumbuh kembang; (3) Prinsip-prinsip pertumbuhan dan perkembangan; (4) Tujuan dan sasaran SDIDTK; (5) Aspek-aspek perkembangan yang dipantau (aspek motorik atau gerak kasar, aspek motorik atau gerak halus, aspek kemampuan bicara dan bahasa serta aspek sosialiasi dan kemandirian); dan (6) Pelaksana dan tempat pelaksanaan SDIDTK; dan (7) Bagaimana cara deteksi penyimpangan dini pada anak. Pelaksanaan kegiatan Edukasi dan Pelatihan SDIDTK berjalan dengan lancar memperoleh hasil sesuai tujuan kegiatan. Tujuan PKM diukur dengan melakukan evaluasi kepada Kader Posyandu dengan memberikan pre test pada awal kegiatan dan post test pada akhir kegiatan.

Hasil yang diperoleh terdapat peningkatan pengetahuan SDIDTK. Hasil pre test kader posyandu Kenanga dan Melati masing-masing diperoleh nilai 44 dan 60 dan terjadi peningkatan nilai post test menjadi 70 dan 70 (Tabel 2).

\section{Peningkatan Ketrampilan Kader Melakukan SDIDTK}

Edukasi kesehatan merupakan penerapan dalam pendidikan di bidang kesehatan dengan kegiatan memberikan dan meningkatkan pengetahuan, sikap, praktik pada individu, kelompok maupun komunitas dalam upaya promotif dan preventif (Notoatmodjo, 2012). 


\section{Tabel 1. Instrumen KPSP Anak Umur 12 Bulan Untuk SDIDTK}

\section{KPSP PADA ANAK UMUR 12 BULAN}

Alat dan bahan yang dibutuhkan:

- Pensil

- Kismis

- 2 Kubus

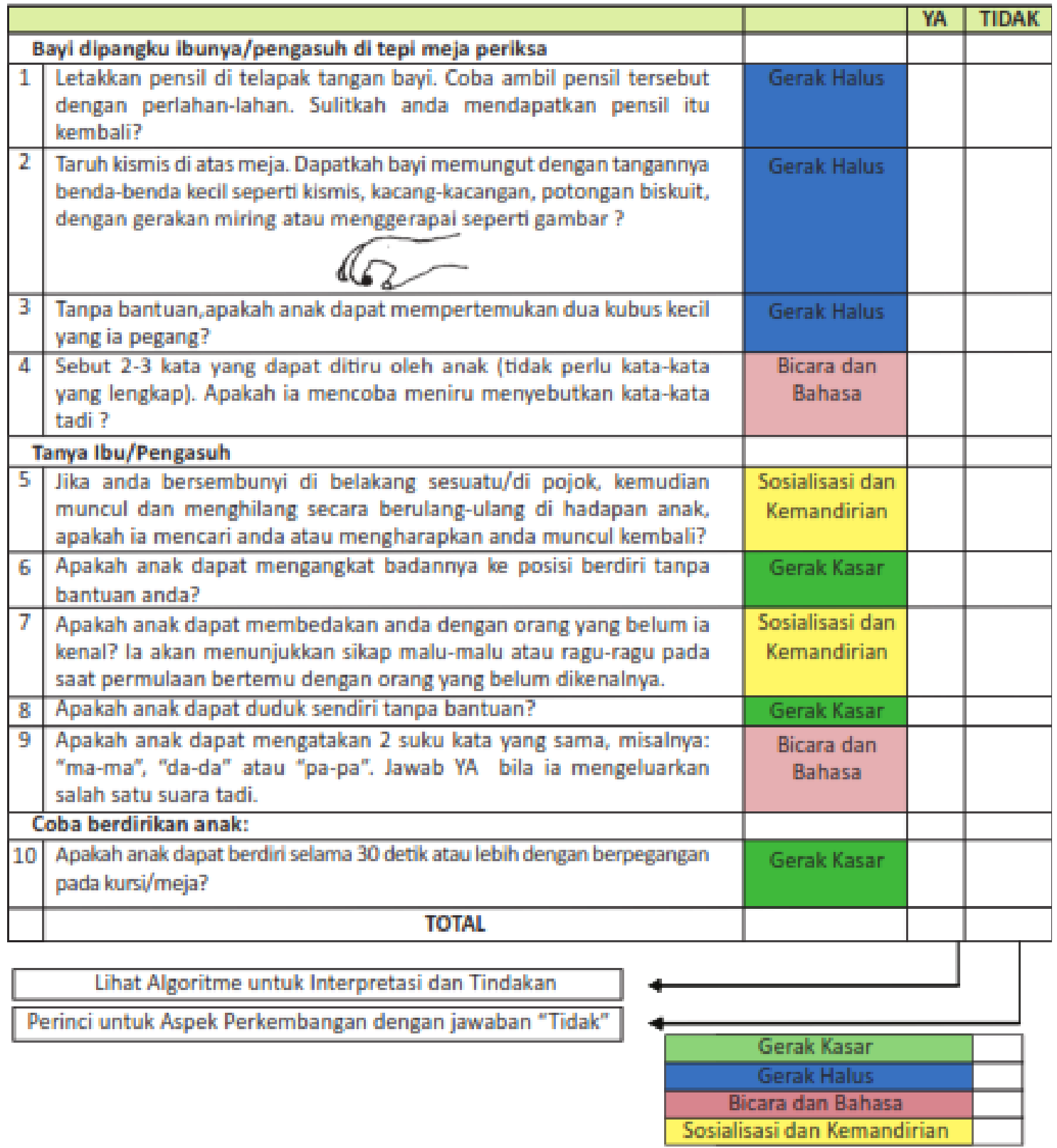

(Sumber: Kemenkes RI., 2016).

Riyanto, Herlina, Islamiyati, Peningkatan Pengetahuan dan Kemampuan Kader Posyandu dalam Stimulasi I Ntervensi dan Deteksi Dini Tumbuh Kembang Anak

di Kelurahan Hadimulyo Barat Kota Metro 
Tabel 2. Hasil Pre Test dan Post Test Edukasi tentang SDIDTK pada Kader

\begin{tabular}{lcc}
\hline \multirow{2}{*}{ Penilaian } & \multicolumn{2}{c}{ Nilai Rata-rata Pengetahuan SDIDTK pada Kader } \\
\cline { 2 - 3 } & $\begin{array}{c}\text { Kader Posyandu Kenanga } \\
(\mathbf{n}=7)\end{array}$ & $\begin{array}{c}\text { Kader Posyandu Melati } \\
(\mathbf{n}=7)\end{array}$ \\
\hline Pre test & 44 & 60 \\
Post test & 70 & 70 \\
\hline
\end{tabular}

Sehingga, edukasi kesehatan tentang SDIDTK dilakukan oleh Tim PKM kepada masyarakat, terlebih Kader dan orang tua untuk mencapai perkembangan anak yang optimal.

PKM ini sejalan dengan kegiatan oleh Hendrawati, Mardhiyah, Mediani, Nurhidayah, Mardiah, Adistie, \& Maryam (2018) diperoleh hasil bahwa terdapat peningkatan pengetahuan tentang SDIDTK dan tumbuh kembang pada anak. Namun, peningkatan pada kegiatan ini nilai rerata pengetahuan baru mencapai 70. Faktor individu belajar, materi pembelajaran, penataan ruang pelatihan menjadi penghambat dalam pelatihan deteksi dini tumbuh kembang anak, sehingga hasil belum optimal. Walaupun, kader sudah diberikan modul pelatihan SDIDTK. Untuk itu, perlu upaya pelaksanaan pelatihan SDIDTK pada kader posyandu dilanjutkan secara berkesinambungan untuk meningkatkan kemampuan kader dalam melakukan stimulasi tumbuh kembang, deteksi dini tumbuh kembang, dan intervensi dini tumbuh kembang, sehingga penyimpangan perkembangan anak dapat diminimalkan.

Penilaian tumbuh kembang anak perlu mendapatkan perhatian serius, secara khusus sampai usia 2 tahun sebagai periode untuk deteksi dini, agar bila ditemukan kecurigaan penyimpangan dapat dilakukan stimulasi dan intervensi dini sebelum terjadi kelainan. Hasil pelatihan ratarata kader mampu melakukan praktik SDIDTK dengan instrumen KPSP dengan baik, walaupun ada sebagain kader perlu pendampingan dengan 
mengulangi praktik. Kader Posyandu Kenanga $100 \%$ mampu melakukan SDIDTK sesuai umur anak, sedangkan Kader Posyandu Melati terdapat 1 (12,5\%) belum mampu (kurang) melakukan SDIDTK sesuai umur anak. Bayi dan balita yang dinilai perkembanggannya diperoleh hasil semua perkembangannya sesuai, baik di posyandu Kenanga yang berjumlah
12 anak maupun posyandu Melati yang berjumlah 7 anak (Tabel 3). Namun demikian, pelatihan tidak memungkinkan untuk melatih Kader melakukan SDIDTK untuk semua umur bayi balita dari $3-72$ bulan. Penyebabnya karena keterbatasan anak dengan umur tersebut dan waktu baik Kader maupun Tim.

Tabel 3. Hasil Penilaian Anak dengan KPSP Tahun 2016 dan Kemampuan Kader Melakukan SDIDTK dengan KPSP Tahun 2016

\begin{tabular}{|c|c|c|c|c|c|}
\hline \multirow{2}{*}{$\begin{array}{c}\text { Penilaian } \\
\text { Aspek } \\
\text { Perkembanga } \\
\text { n }\end{array}$} & \multicolumn{3}{|c|}{$\begin{array}{c}\text { Jumlah Hasil Stimulasi terhadap } \\
\text { Bayi Balita dengan KPSP }\end{array}$} & \multicolumn{2}{|c|}{$\begin{array}{c}\text { Kemampuan Kader } \\
\text { Melakukan } \\
\text { SDIDTK } \\
\end{array}$} \\
\hline & $\begin{array}{c}\text { Sesuai } \\
\text { Nilai (9- } \\
10) \\
\end{array}$ & $\begin{array}{l}\text { Meragukan } \\
\text { (Nilai 7-8) }\end{array}$ & $\begin{array}{c}\text { Keterlambat } \\
\text { an } \\
\text { (Nilai } \leq 6)\end{array}$ & Baik & Kurang \\
\hline $\begin{array}{l}\text { Kader } \\
\text { Posyandu } \\
\text { Kenanga }(n=7)\end{array}$ & $12(100 \%)$ & 0 & 0 & $\begin{array}{c}12 \\
(100 \%)\end{array}$ & 0 \\
\hline $\begin{array}{l}\text { Kader } \\
\text { Posyandu } \\
\text { Melati }(n=7)\end{array}$ & 7 (100\%) & 0 & 0 & $\begin{array}{c}7 \\
(87,5 \%)\end{array}$ & $1(12,5 \%)$ \\
\hline
\end{tabular}

Hasil PKM ini dikuatkan oleh penelitian sebelumnya bahwa pengetahuan dan ketrampilan kader Posyandu dapat ditingkatkan dengan edukasi dan pelatihan. Edukasi meningkatkan pengetahuan dan keterampilan ibu baik Kader maupun orang tua dalam menstimulasi tumbuh kembang balita segera setelah pelatihan (Muflihah, 2017). Efeknya positif dalam meningkatkan perkembangan bahasa dan memori 
anak, kesiapan anak dalam sekolah dan membantu anak untuk memaksimalkan potensi dalam hidup mereka (Abidah, \& Novianti, 2020). Penelitian oleh Yanto, Maemunah, \& Hastutiningtyas, (2021) memperoleh hasil ada pengaruh pemberian pelatihan perkembangan bayi dan anak terhadap kemampuan kader dalam mendeteksi perkembangan bayi dan anak ( 3 bulan -6 tahun).

Kegiatan stimulasi dan deteksi dini tumbuh kembang balita diharapkan memberi dampak langsung kepada peningkatan pembangungan sumber daya manusia yang harus dimulai sejak dini. Karena, pada lima tahun pertama kehidupan manusia, proses tumbuh kembang berjalan sangat cepat dan sebagai masa emas (Golden Age Period) khususnya pada usia 0-2 tahun perkembangan otak mencapai 80 persen. Apabila pada masa tersebut anak balita tidak dibina secara baik, maka anak tersebut akan mengalami gangguan perkembangan baik emosi, sosial, mental, intelektual dan moral yang akan sangat menentukan sikap serta nilai pola perilaku seseorang di kemudian hari (Soetjiningsih, \& Ranuh, 2017).

Untuk itu, pemberdayaan kader dalam stimulasi dan mendeteksi penyimpangan dini anak hendaknya dilakukan secara berkesinambungan baik oleh Pemerintah maupun organisasi nonpemerintah. Sehingga, anak pada periode emas perkembangan anak 1000 hari yang dimulai dari janin dalam kandungan ibu dapat optimal.

\section{SIMPULAN}

Pelaksanaan kegiatan Penyuluhan dan Pelatihan SDIDTK berjalan dengan lancar memperoleh hasil sesuai tujuan kegiatan Pengabdian kepada Masyarakat. Kesimpulan kegiatan ini terjadi peningkatan pengetahuan tentang SDDTK dan kemampuan melakukan stimulasi perkembangan dengan KPSP oleh Kader Posyandu. Adanya

Riyanto, Herlina, Islamiyati, Peningkatan Pengetahuan dan Kemampuan Kader Posyandu dalam Stimulasi I Ntervensi dan Deteksi Dini Tumbuh Kembang Anak 
partisipasi, kerja sama dan saling mendukung yang sangat baik dari pihak masyarakat Hadimulyo Barat kecamatan Metro Pusat, yaitu Lurah, Bidan mewakili Puskesmas, Kader Posyandu dan Ibu Balita dengan Dosen Prodi Kebidanan Metro. Namun, masih diperlukan pelatihan dengan melibatkan bayi balita dari berbagai umur sesuai instrumen KPSP dan pendampingan saat Kader melakukan SDIDTK langsung pada kegiatan Posyandu.

\section{UCAPAN TERIMA KASIH}

Terima kasih kami ucapkan kepada Poltekkes Tanjungkarang yang telah berkenan memberikan dana untuk kegiatan Pengabdian kepada Masyarakat oleh Tim Kelompok 3 Dosen Prodi Kebidanan Metro dan kepada Mitra, yaitu Dinas Kesehatan kota Metro.

\section{DAFTAR PUSTAKA}

Abidah, S. N., \& Novianti, H. (2020). Pengaruh Edukasi Stimulasi Tumbuh Kembang terhadap Kemampuan Deteksi Dini Tumbuh Kembang Anak Usia 05 Tahun oleh Orangtua. Poltekita: Jurnal Ilmu Kesehatan, 14(2), 89-93. https://doi.org/10.33860/jik.v14i2 .132

Badan Litbang Kemenkes RI. (2019). Laporan Provinsi Lampung Riskesdas 2018. Jakarta: Lembaga Penerbit Badan Litbang Kesehatan

Hendrawati, S., Mardhiyah, A., Mediani, H. S., Nurhidayah, I., Mardiah, W., Adistie, F., \& Maryam, N. N. A. (2018). Pemberdayaan Kader Posyandu dalam Stimulasi Deteksi dan Intervensi Dini Tumbuh Kembang (SDIDTK) pada Anak Usia 0-6 Tahun di Desa Cileles Kecamatan Jatinangor 
Kabupaten Sumedang. Media Karya Kesehatan, 1(1). https://doi.org/10.24198/mkk.v1i 1.17263

Kadi, F. A., Garna, H., \& Fadlyana, E. (2016). Kesetaraan hasil skrining risiko penyimpangan perkembangan menurut cara kuesioner praskrining perkembangan (KPSP) dan denver II pada anak usia 12-14 bulan dengan berat lahir rendah. Sari Pediatri, 10(1), 29-33.

Kemenkes RI. (2020). Kurikulum pelatihan stimulasi, deteksi dan intervensi dini tumbuh kembang. Jakarta: Direktorat Kesehatan Keluarga Dirjend. Kesmas Kemenkes RI

Soetjiningsih \& Ranuh (2017). Tumbuh kembang anak (Ed. 2). Jakarta: Penerbit Buku Kedokteran EGC Yanto, B., Maemunah, N., \& Hastutiningtyas, W. R. (2021). Pengaruh Pemberian Pelatihan Tlogomas Malang (Doctoral dissertation, Fakultas Ilmu
Kemenkes RI. (2016). Pedoman pelaksanaan stimulasi deteksi dan intervensi dini tumbuh kembang anak ditingkat pelayanan kesehatan dasar. Jakarta: Kemenkes RI

Muflihah, I. S. (2017). Efektifitas Pelatihan Deteksi Dini Tumbuh Kembang Sesuai Tahapan Usia Anak Terhadap Pengetahuan Dan Keterampilan Ibu Dalam Menstimulasi Tumbuh Kembang Balita. MEDISAINS, 13(1).

http://dx.doi.org/10.30595/medis ains.v13i1.1822

Notoadmodjo, S. (2012). Promosi kesehatan dan perubahan kesehatan. Jakarta: PT Renika Cipta

Perkembangan Bayi dan Anak Terhadap Kemampuan Kader dalam Mendeteksi Perkembangan Bayi dan Anak (3 Bulan-6 Tahun) di Posyandu Mawar Kelurahan RW 06

Kesehatan Universitas

Tribhuwana Tunggadewi). 
https://rinjani.unitri.ac.id/hand

le/071061/448

Riyanto, Herlina, Islamiyati, Peningkatan Pengetahuan dan Kemampuan Kader Posyandu dalam Stimulasi I Ntervensi dan Deteksi Dini Tumbuh Kembang Anak di Kelurahan Hadimulyo Barat Kota Metro 